\title{
THE IMPACT OF VARYING LEVELS OF COMPETITION FROM PEARL MILLET ON THE YIELDS OF GROUNDNUT CULTIVARS
}

\author{
By B. J. NDUNGURU and J. H. WILLIAMS \\ ICRISAT Sahelian Center, BP 12404, Niamey, Niger
}

(Accepted 29 January 1992)

\begin{abstract}
SUMMARY
A series of trials investigated the response of a range of groundnut genotypes to varied levels of competition from millet in intercrop situations in both the Sahelian and Sudanian agro-climatic zones. No genotype interactions were observed in response to different millet population levels. Introducing millet into groundnut cultivation provided considerable benefits to the farmer, particularly at the less dense millet populations, but the introduction of groundnut into millet cropping consistently reduced the yield of millet, with little gain in groundnut yields.
\end{abstract}

El impacto de distintos niveles de competencia de mijo perlado en el rendimiento de variedades de cultivo de chufa

\section{RESUMEN}

Una serie de pruebas investigaron la respuesta de un grupo de genotipos de chufa respecto de diversos niveles de competencia de mijo en situaciones de siembra simultánae, en la zona agroclimática de Sahel y Sudán. No se observó ningún tipo de interacción genotípica en respuesta a los diferentes niveles de población de mijo. La introducción del mijo a los cultivos de chufa brindó ventajas considerables para los agricultores, en particular, en las poblaciones de mijo de menor densidad, pero la introducción de chufa a los cultivos de mijo cn todos los casos redujo el rendimiento de mijo, con escaso incremento en el rendimiento de la chufa.

\section{INTRODUCTION}

Groundnut was introduced to West Africa by Portuguese traders and was cultivated before the end of the last century. Considerable research has been carried out in West Africa, for example by French institutions, to develop groundnut varieties and agronomic packages for various agroclimatic zones (Bockelée-Morvan, 1983). Most of this resulted in production technologies which featured groundnut as a sole crop. These recommendations were followed as long as the farmers were assured of a market once they had produced the crop. But with a slump in the export market demand for groundnuts, production systems changed and farmers encountered the same problems that characterize the production of other subsistence crops in sub-Saharan Africa.

The most common cropping systems in the West African semi-arid tropics (WASAT) consist of several crops grown in association or mixture. This method 
provides the farmer with a variety of returns from land and labour, often increases the efficiency with which scarce resources are used and reduces dependence upon a single crop that is susceptible to environmental and economic fluctuations (Steiner, 1982). Intercropping can reduce soil erosion (Bonsu and Obeng, 1979) and often provides a balanced diet. Mixed cropping presents some difficulties to mechanization, but where the hoe is the main agricultural implement this is not a major concern. Indeed, the introduction of pure stand rotational systems of agriculture based on hand tillage may be difficult (Marenah, 1990).

In a survey in Niger in 1988 (Ndunguru, 1991), we found that about $66 \%$ of the farmers grew groundnut in association with other crops, although the practice was discouraged by research and extension agencies (Morris, 1989). In northern Nigeria sorghum and pearl millet (or their mixture) are intercropped with groundnuts. Normally a cereal is sown at the very earliest opportunity and at a wide spacing. Intercropping is then practised, with more cereal sown or groundnut planted depending on the subsequent development of the rains (Baker, 1979).

In their extensive review of crop associations in West Africa, Fussell and Serafini (1985) recommended that when choosing any crop combination, specific varietal characteristics need to be considered. Because the existing varieties of groundnut were developed and selected in a sole crop situation and are now being grown as intercrops, we investigated the impact of varying levels of competition from pearl millet on the yields of these groundnut cultivars. The intercrop introduces a change in the pattern of competition for resources relative to that in a sole crop and a description of this competition and differences (if any) in the response of different varieties is needed.

\section{MATERIALS AND METHODS}

The trials were conducted during the rainy seasons in 1988 and 1989 (June to October) at Sadoré, the research farm of the International Crops Research Institute for the Semi-Arid Tropics (ICRISAT) Sahelian Center (latitude $13^{\circ} 29^{\prime} \mathrm{N}$, longitude $2^{\circ} 10^{\prime} \mathrm{E}$, altitude $221 \mathrm{~m}$ above sea level), $45 \mathrm{~km}$ south of Niamey, Niger, and in 1988 at Bengou, Niger $\left(11^{\circ} 5^{\prime} \mathrm{N}, 3^{\circ} 30^{\prime} \mathrm{E}, 160 \mathrm{~m}\right.$ asl $)$, and in 1989 at Tara, near Bengou. The Bengou and Tara sites were on the Institut National de Recherche Agronomique du Niger (INRAN) stations in the SudanoSahelian agro-climatic zone, with a mean rainfall of $850 \mathrm{~mm}$. The long-term mean annual rainfall at Sadoré is $560 \mathrm{~mm}$ and the rainfall exceeds potential evapotranspiration for a very short period. Rainfall during the experiments is shown in Table 1. The soils are Psammentic Paleustalf (sandy, siliceous, isohyperthermic) with poor inherent fertility and little organic matter (Table 1).

Two locally recommended and released groundnut lines and an introduced ICRISAT line were grown at each site. The cultivars used at Sadoré were 55-437, TS 32-1, and ICGS(E) 11 (all 90 day Spanish bunch types). At Bengou and Tara the groundnut cultivars used were 28-206 (a 120 day Virginia bunch), 47-16 (a 120 day Virginia runner), and ICGS(E) 11. These cultivars represented the 
Table 1. Rainfall distribution and totals, and soil properties, for the experimental sites

\begin{tabular}{|c|c|c|c|c|}
\hline & \multicolumn{2}{|c|}{ Sadoré } & \multirow{2}{*}{$\begin{array}{c}\text { Bengou } \\
1988\end{array}$} & \multirow{2}{*}{$\begin{array}{l}\text { Tara } \\
1989\end{array}$} \\
\hline & 1988 & 1989 & & \\
\hline \multicolumn{5}{|c|}{ Rainfall $(\mathrm{mm})$} \\
\hline May & 1 & 35 & 74 & 0 \\
\hline June & 90 & 36 & 178 & 59 \\
\hline July & 173 & 92 & 235 & 147 \\
\hline August & 239 & 234 & 277 & 189 \\
\hline September & 187 & 198 & 161 & 98 \\
\hline October & 0 & 278 & 7 & 38 \\
\hline Total & 690 & 623 & 932 & 530 \\
\hline \multicolumn{5}{|c|}{ Soil properties } \\
\hline Sand $(\%)$ & & 96 & 76.8 & 89.3 \\
\hline Clay $(\%)$ & & 1.3 & 4.7 & 3.1 \\
\hline Total $\mathrm{P}\left(\mathrm{mg} \mathrm{kg}^{-1}\right)$ & & 68 & 114 & 129 \\
\hline Total $N\left(\mathrm{mg} \mathrm{kg}^{-1}\right)$ & & 123 & 298 & 197 \\
\hline Availablc P (Bray Pl, $\mathrm{mg} \mathrm{kg}^{-1}$ ) & & 2.8 & 1.7 & 3.3 \\
\hline $\mathrm{pH}(\mathrm{KCl})$ & & 4.4 & 4.7 & 4.1 \\
\hline \multicolumn{5}{|l|}{ Effective cation exchange } \\
\hline Organic matter (\%) & & 0.4 & 1.4 & 0.4 \\
\hline
\end{tabular}

maturity range adapted to the various environments. The pearl millet cultivar CIVT was used in all trials.

All plots received a basal dressing of single superphosphate at a rate of $36 \mathrm{~kg}$ $\mathrm{P}_{2} \mathrm{O}_{5} \mathrm{ha}^{-1}$. Calcium ammonium nitrate (CAN) was applied to pearl millet plants at a rate of $10 \mathrm{~kg} \mathrm{~N} \mathrm{ha}^{-1}$ in two splits and groundnuts received $400 \mathrm{~kg} \mathrm{ha}^{-1}$ gypsum at pegging. The groundnut was grown at a spacing of $50 \times 10 \mathrm{~cm}$ as a sole crop, or between the rows of pearl millet hills where intercropped. The trials were laid out in a randomized block design replicated four times with 15 treatments (Table 2).

At Sadoré the sowing dates were 11 June 1988 and 29 June 1989, at Bengou 20 June 1988, and at Tara 24 June 1989. Plots were kept weed free by hand hoeing. Yield was estimated by harvesting an area of $30 \mathrm{~m}^{2}$ from each plot.

Pearl millet and groundnut yields were statistically analysed separately. Where the introduction of crop $X$ into a sole crop $Y$ decreased the yield of $Y$, we investigated the competitive interaction between the two components of the intercrop by computing a compensation ratio (CR) for the grain, fodder and total biomass using the equation:

$$
\mathrm{CR}=\mathrm{X}_{\mathrm{i}} /\left(\mathrm{Y}-\mathrm{Y}_{\mathrm{i}}\right)
$$

where $X_{i}$ is the yield of crop 1 in the intercrop, $Y$ the yield of crop 2 in monocrop and $Y_{i}$ the yield of crop 2 in the intercrop. Thus the compensation ratio indicates the gain of the introduced component relative to its competitive 
Table 2. Pearl millet spacing and groundnut cultivar combinations

\begin{tabular}{cccc}
\hline & \multicolumn{2}{c}{ Groundnut cultivar } & $\begin{array}{c}\text { Millet } \\
\text { spacing, } \\
\text { all sites }\end{array}$ \\
\cline { 2 - 4 } Treatment & Sadoré & Tara and Bengou & \\
1 & $55-437$ & $28-206$ & - \\
2 & TS-32-1 & $47-16$ & - \\
3 & ICGS(E) 11 & ICGS(E) 11 & - \\
4 & - & - & $1 \times 1 \mathrm{~m}$ \\
5 & - & - & $1 \times 2 \mathrm{~m}$ \\
6 & - & - & $1 \times 3 \mathrm{~m}$ \\
7 & $55-437$ & $28-206$ & $1 \times 1 \mathrm{~m}$ \\
8 & $55-437$ & $28-206$ & $1 \times 2 \mathrm{~m}$ \\
9 & $55-437$ & $28-206$ & $1 \times 3 \mathrm{~m}$ \\
10 & TS-32-1 & $47-16$ & $1 \times 1 \mathrm{~m}$ \\
11 & TS-32-1 & $47-16$ & $1 \times 2 \mathrm{~m}$ \\
12 & TS-32-1 & $47-16$ & $1 \times 3 \mathrm{~m}$ \\
13 & ICGS(E) 11 & ICGS(E) 11 & $1 \times 1 \mathrm{~m}$ \\
14 & ICGS(E) 11 & ICGS(E) 11 & $1 \times 2 \mathrm{~m}$ \\
15 & ICGS(E) 11 & ICGS(E) 11 & $1 \times 3 \mathrm{~m}$ \\
\hline
\end{tabular}

impact on the companion crop. With the data set available it was possible to examine both the impact of pearl millet at varying densities on a sole groundnut crop, and the impact of groundnut (and varieties of groundnut) on the pearl millet crops.

\section{RESULTS}

Generally, the pod yields of groundnut decreased as the level of competition from pearl millet increased from nil (sole groundnut) to the most dense pearl millet stands $(1 \times 1)$; the exception was for TS 32-1 at Sadore in 1989, where the sole crop had smaller yields than in the least dense pearl millet crop (Table 3). The smallest pod yields were obtained when groundnuts were intercropped with pearl millet grown at $1 \times 1 \mathrm{~m}$, but this planting pattern invariably gave the maximum yields of pearl millet grain. There was no significant difference in yield between groundnut cultivars within the ecological zones and at different levels of pearl millet intercrop competition. Pearl millet seed yield was usually reduced as a result of being intercropped with groundnut. This effect was greatest at Sadoré, particularly in 1989 when the pearl millet yields were approximately halved by the groundnut intercrop at all population levels of pearl millet.

The trends in haulm and straw production were similar to those observed for pods (Table 4 ). The smallest haulm yield was recorded when groundnut was grown in association with pearl millet at $1 \times 1 \mathrm{~m}$. Overall there was no significant varietal difference in haulm yield. The poorest yields were recorded at Sadoré. Yields at Bengou and Tara were similar. 
Table 3. Groundnut pod and pearl millet seed yields ( $t \mathrm{ha}^{-1}$ ) for sole crop and intercrop treatments (treatment codes as in Table 2)

\begin{tabular}{|c|c|c|c|c|c|c|c|c|}
\hline & \multicolumn{4}{|c|}{ Groundnut pod yield } & \multicolumn{4}{|c|}{ Pearl millet seed yield } \\
\hline & \multicolumn{2}{|c|}{ Sadoré } & \multirow{2}{*}{$\begin{array}{c}\text { Bengou } \\
1988\end{array}$} & \multirow{2}{*}{$\begin{array}{l}\text { Tara } \\
1989\end{array}$} & \multicolumn{2}{|c|}{ Sadoré } & \multirow{2}{*}{$\begin{array}{c}\text { Bengou } \\
1988\end{array}$} & \multirow{2}{*}{$\begin{array}{l}\text { Tara } \\
1989\end{array}$} \\
\hline & 1988 & 1989 & & & 1988 & 1989 & & \\
\hline \multicolumn{9}{|c|}{ Treatment } \\
\hline 1 & 1.37 & 0.46 & 1.42 & 1.29 & - & - & - & - \\
\hline 2 & 1.34 & 0.29 & 2.30 & 0.99 & - & - & - & - \\
\hline 3 & 1.11 & 0.51 & 2.19 & 1.40 & - & - & - & - \\
\hline 4 & - & - & - & - & 0.89 & 0.41 & 1.23 & 1.29 \\
\hline 5 & - & - & - & - & 0.49 & 0.22 & 0.50 & 0.82 \\
\hline 6 & - & - & - & - & 0.33 & 0.13 & 0.31 & 0.38 \\
\hline 7 & 0.42 & 0.13 & 0.60 & 0.71 & 0.61 & 0.21 & 0.97 & 1.20 \\
\hline 8 & 0.78 & 0.33 & 0.93 & 1.05 & 0.20 & 0.11 & 0.56 & 0.56 \\
\hline 9 & 1.12 & 0.44 & 1.08 & 1.38 & 0.16 & 0.09 & 0.19 & 0.28 \\
\hline 10 & 0.49 & 0.17 & 0.69 & 0.66 & 0.75 & 0.27 & 0.99 & 1.04 \\
\hline 11 & 0.92 & 0.27 & 1.28 & 1.03 & 0.24 & 0.13 & 0.30 & 0.54 \\
\hline 12 & 1.17 & 0.49 & 1.54 & 0.98 & 0.18 & 0.07 & 0.16 & 0.27 \\
\hline 13 & 0.53 & 0.20 & 0.78 & 0.71 & 0.73 & 0.22 & 1.08 & 1.31 \\
\hline 14 & 0.93 & 0.35 & 1.30 & 1.11 & 0.24 & 0.16 & 0.30 & 0.58 \\
\hline 15 & 0.94 & 0.47 & 1.68 & 1.26 & 0.19 & 0.05 & 0.19 & 0.24 \\
\hline SE & 0.10 & 0.09 & 0.10 & 0.08 & 0.08 & 0.02 & 0.08 & 0.05 \\
\hline
\end{tabular}

In some treatments the intercrop yielded the same, or slightly (but nonsignificantly) more than the sole crop, and in these cases no compensation ratio was computed. For the other treatments compensation ratios were computed from the point of view of both the introduction of groundnut into a pure pearl millet crop (Table 5), and the introduction of pearl millet into a monocrop of groundnut (Table 6).

Generally the introduction of groundnut into pearl millet at any of the spacings substantially decreased the yield of both the straw and grain of pearl millet. This did not vary significantly with groundnut genotype. In the case of pearl millet and groundnut fodder, this decrease was well compensated for, because each unit of pearl millet straw lost resulted in between 1.5 and 4 units of groundnut fodder. The exception was the experiment at Bengou (which experienced severe defoliation due to leaf spot diseases and where the CR was less than 1). In the case of grain, the introduction of groundnut into pearl millet resulted in between 1.5 and 4 units of groundnut pods for each unit of pearl millet grain sacrificed. The exception was at Sadore in 1988 where the CR for grain was adverse.

When the introduction of pearl millet into a sole groundnut crop was considered, there were increases in the groundnut:pearl millet compensation ratios with increasing pearl millet spacing in the intercrops. In all cases the most profitable intercrop arrangement in terms of pearl millet grain and straw yield per 


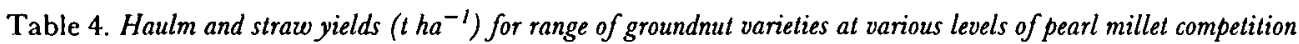
(treatment codes as in Table 2)

\begin{tabular}{|c|c|c|c|c|c|c|c|c|}
\hline & \multicolumn{4}{|c|}{ Haulm yield } & \multicolumn{4}{|c|}{ Straw yield } \\
\hline & \multicolumn{2}{|c|}{ Sadoré } & \multirow{2}{*}{$\begin{array}{c}\text { Bengou } \\
1988\end{array}$} & \multirow{2}{*}{$\begin{array}{l}\text { Tara } \\
1989\end{array}$} & \multicolumn{2}{|c|}{ Sadoré } & \multirow{2}{*}{$\begin{array}{c}\text { Bengou } \\
1988\end{array}$} & \multirow{2}{*}{$\begin{array}{l}\text { Tar } \\
198\end{array}$} \\
\hline & 1988 & 1989 & & & 1988 & 1989 & & \\
\hline \multicolumn{9}{|c|}{ Treatment } \\
\hline 1 & 1.33 & 0.53 & 3.09 & 2.62 & - & - & - & - \\
\hline 2 & 1.64 & 0.49 & 3.11 & 3.13 & - & - & - & - \\
\hline 3 & 1.18 & 0.70 & 3.05 & 2.59 & - & - & - & - \\
\hline 4 & - & - & - & - & 3.00 & 1.24 & 4.37 & 3.70 \\
\hline 5 & - & - & - & - & 1.29 & 0.59 & 2.55 & 1.94 \\
\hline 6 & - & - & - & - & 0.77 & 0.33 & 1.58 & 0.98 \\
\hline 7 & 0.53 & 0.21 & 1.44 & 1.28 & 2.12 & 0.67 & 3.35 & 2.95 \\
\hline 8 & 0.75 & 0.44 & 2.44 & 1.87 & 0.78 & 0.33 & 1.28 & 1.35 \\
\hline 9 & 1.19 & 0.60 & 2.83 & 2.37 & 0.57 & 0.27 & 0.76 & 0.60 \\
\hline 10 & 0.63 & 0.27 & 1.39 & 1.44 & 2.18 & 0.82 & 3.17 & 3.05 \\
\hline 11 & 1.09 & 0.49 & 2.22 & 2.45 & 0.97 & 0.42 & 1.52 & 1.55 \\
\hline 12 & 1.41 & 0.86 & 2.83 & 2.63 & 0.50 & 0.17 & 0.88 & 0.59 \\
\hline 13 & 0.62 & 0.31 & 1.35 & 1.22 & 1.57 & 0.64 & 3.47 & 3.32 \\
\hline 14 & 0.93 & 0.52 & 2.28 & 1.72 & 0.87 & 0.40 & 1.42 & 1.16 \\
\hline 15 & 1.01 & 0.66 & 2.64 & 2.15 & 0.60 & 0.19 & 0.76 & 0.61 \\
\hline $\mathrm{SE}$ & 0.10 & 0.10 & 0.09 & 0.17 & 0.20 & 0.09 & 0.11 & 0.17 \\
\hline
\end{tabular}

unit decrease in groundnut pods and haulm yield was obtained when the least dense population of pearl millet was used. This trend was observed at all sites.

\section{DISCUSSION}

The lack of groundnut genotype $\times$ pearl millet density interactions suggests that there may be no need to select groundnut varieties specifically for the more complex environment of an intercrop as advocated by Fussel and Serafini (1985). Although Remison (1978) observed an increase in maize yields as a result of intercropping with cowpea in Nigeria, and Osiru and Willey (1972) similarly showed that yields of dwarf sorghum could be maintained over a wide range of spatial arrangements in bean intercrops in Uganda, in our trials a legume intercrop reduced cereal yield. The decrease in pearl millet yield as a result of the presence of groundnut seems likely to be due to competition for water because the effect was least at Bengou, and greatest at Sadore in 1988 which received less rain. Haerdter (1989) in northern Nigeria also obtained different results depending on the climatic conditions and management levels under which the experiments were carried out.

Groundnut pod yields were reduced when grown in association with pearl millet, but the decrease was only statistically significant once the pearl millet population exceeded 5000 hills $\mathrm{ha}^{-1}$. This decrease in groundnut yield is to be 
Table 5. Groundnut: pearl millet compensation ratios ( $\mathrm{kg}$ of pearl millet gained per $\mathrm{kg}$ of groundnut sacrificed) for the intercrop treatments (treatment codes as in Table 2)

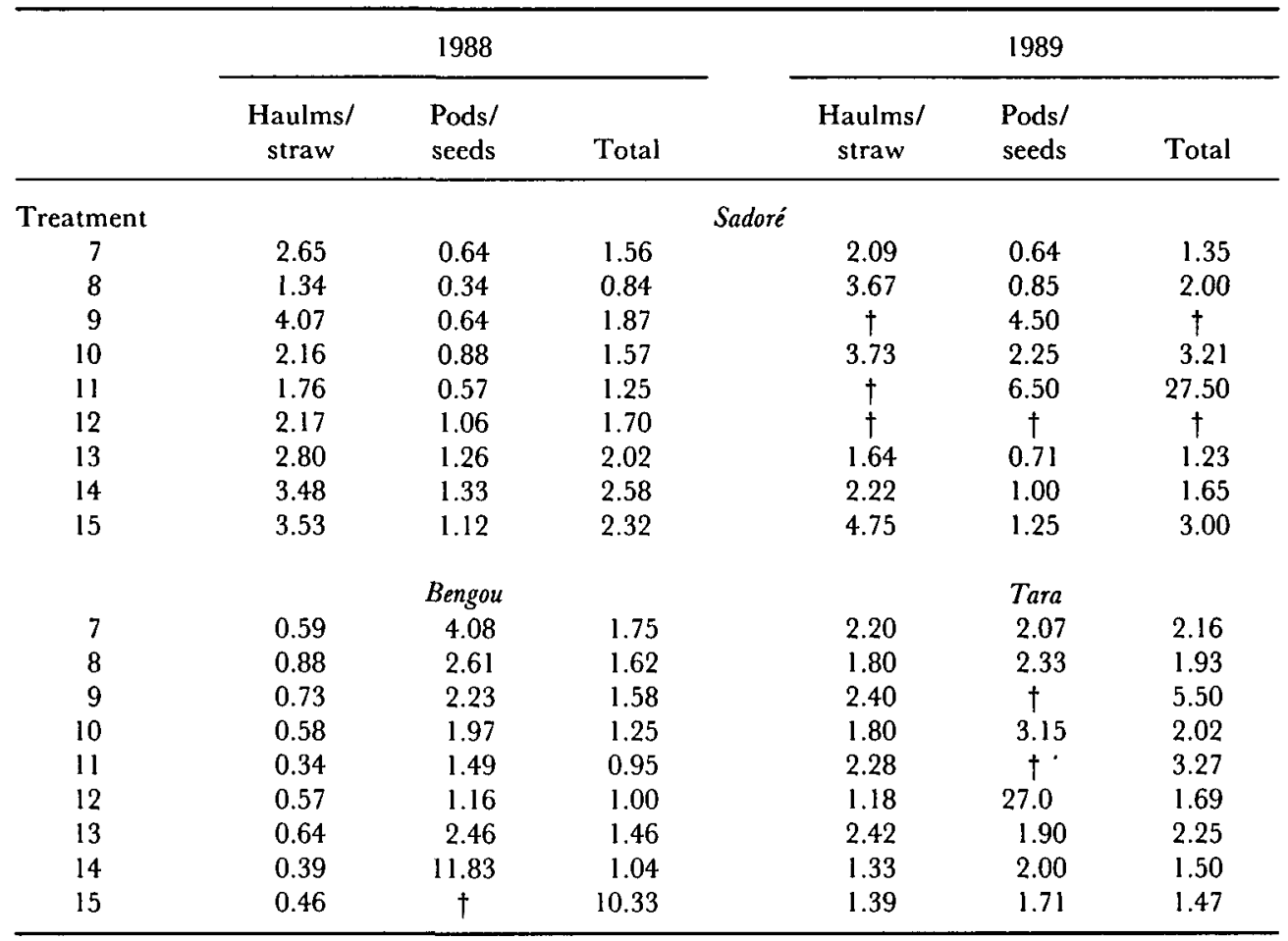

$\dagger$ Denotes cases where introducing groundnut into pearl millet did not decrease pearl millet yield.

expected because the erect canopy architecture of pearl millet provides pearl millet with a competitive advantage for light. The relatively poor yields for both crops recorded at Sadoré in 1989 were probably a reflection of poor rainfall distribution. Serious competition for moisture can occur among intercrops and this can reduce the overall yield of both crops.

The farmers' decision to grow crops in association has been shown by previous researchers to be justified from a number of points of view. Aspects of biological efficiency in intercropping have been evaluated in various ways. Land equivalent ratio (LER), relative yield totals (RYT) and, more recently, bivariate analyses have been used in analysing intercropping data (Pearce and Gilliver, 1979), but these analyses all face the difficulty that the various components of the cropping system have different economic values, and they may also have other limitations. LER does not take land occupation into account (Hiebsch and McCollum, 1987), neither do absolute yields (Willey, 1985). Hiebsch and McCollum (1987) have evaluated productivity in intercropping by considering the use of land and time.

The concept of a compensation ratio between two components of an intercrop provides a clear insight into the options facing a farmer. The amount of cereal grain gained relative to the groundnut yield lost by changing from a sole crop to an 
Table 6. Pearl millet: groundnut compensation ratios ( $k g$ of groundnut gained per $\mathrm{kg}$ of pearl millet sacrificed) for the intercrop treatments (treatment codes as in Table 2)

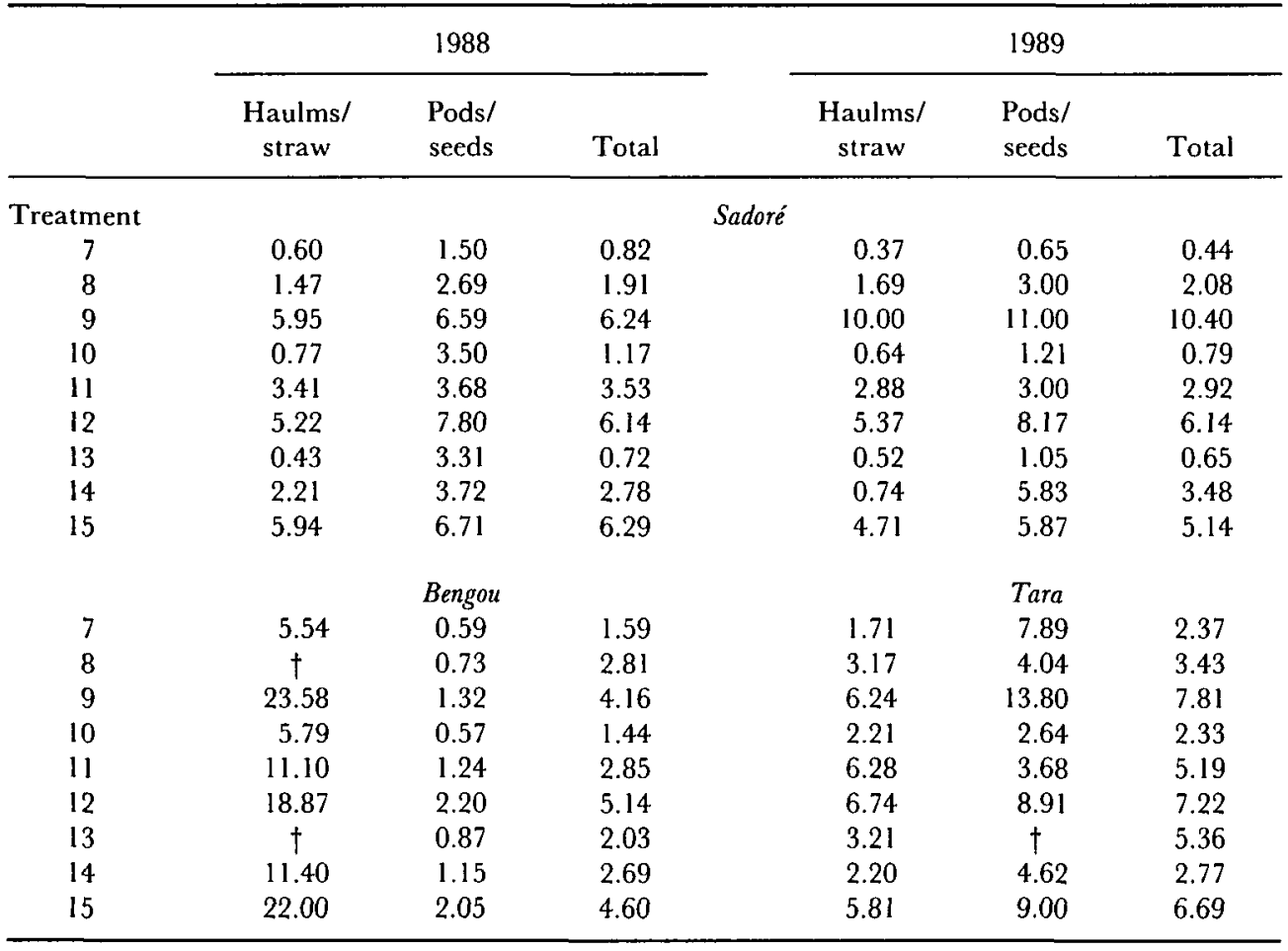

†Denotes cases where introducing pearl millet into groundnut did not decrease groundnut yield.

intercrop system explains the farmers' decision to introduce a cereal crop into their groundnut production. The change has little impact on the yield of groundnut, particularly when the population of pearl millet hills is small, but the farmers gain very considerable amounts (15-25:1) of pearl millet grain for each unit of groundnut lost. Farmers have the opportunity to manipulate the trade ratio by varying the population of pearl millet, depending on their resources of land and labour and their required product blend. However, from the point of view of pearl millet farmers introducing groundnuts into their crop, it is important that the population of pearl millet is maintained at a high level, because the decrease in pearl millet yield associated with intercropping is always high (about $50 \%$ ) and the gains in groundnut relative to the loss of pearl millet relatively modest and constant.

\section{REFERENCES}

Baker, E. F. I. (1979). Mixed cropping in northern Nigeria 1. Cereals and groundnuts. Samaru Research Bulletin 297. Zaria: Ahmadu Bello University.

Bockelée-Morvan, A. (I983). Les différentes variétés d'arachide: répartition géographique et climatique, disponibilité. Oléagineux 38:73-116. 
Bonsu, M. \& Obeng, H. B. (1979). Effects of cultural practices on soil erosion and maize production in the semi-deciduous rainforest and forest-savanna transitional zones of Ghana. In Soil Physical Properties and Crop Production in the Tropics, 509-519 (Eds R. Lal and D. J. Greenland).

Fussell, L. K. \& Serafini, P. (1985). Crop associations in the semi-arid tropics of West Africa. Research strategies past and future. In Appropriate Technologies for Farmers in Semi-Arid West Africa (Eds H. W. Ohm and J. G. Nagy). West Lafayette, Indiana: International Programs in Agriculture, Purdue University.

Haerdter, R. (1989). Utilization of nitrogen and phosphorus by intercropping and sole cropping systems of maize (Zea mays L.) and cowpea (Vigna unguiculata L.) on an alfisol in northern Ghana. In Nyankpala Agricultural Research Report 5 (1989). Weikersheim, Germany: Morgaf Scientific.

Hiebsch, C. K. \& McCollum, R. E. (1987). Area $\times$ time equivalency ratio: A method for evaluating the productivity of intercrops. Agronomy Joumal 79:15-22.

Marenah, L. J. (1990). Overview of problems of groundnut production in Africa. In Summary Proceedings of the First ICRISAT Regional Groundnut Meeting for West Africa 13-14 September 1988, Niamey, Niger. Patancheru, India: ICRISAT.

Morris, W. H. M. (1989). Peanut Production, Marketing, and Export: Senegal, Gambia, Mali, Burkina Faso, and Niger. Griffin, Georgia: Peanut CRSP, The University of Georgia, Georgia Experiment Station.

Ndunguru, B. J. (1991). Survey of groundnut agronomic practices in Niger. In Summary Proceedings of the Second Regional Groundnut Meeting for West Africa, 11-14 September 1990, ICRISAT Sahelian Center, Niamey, Niger. (In Eng., Fr.) Patancheru, India: ICRISAT.

Osiru, D. S. O. \& Willey, R. W. (1972). Studies on mixtures of dwarf sorghum and beans (Phaseolus vulgaris) with particular reference to plant population. Journal of Agricultural Science, Cambridge 79:531540.

Pearce, S. C. \& Gilliver, B. (1979). Graphical assessment of intercropping methods. Journal of Agricultural Science, Cambridge 93:51-58.

Remison, S. U. (1978). Neighbour effects between maize and cowpea at various levels of $\mathrm{N}$ and $\mathrm{P}$. Experimental Agriculture 14:205-212.

Steiner, K. G. (1982). Intercropping in tropical smallholder agriculture with special reference to West Africa. Eschborn, Germany: German Agency for Technical Cooperation (GTZ).

Willey, R. W. (1985). Evaluation and presentation of intercropping advantages. Experimental Agriculture 21:119-133. 